\title{
Synthesis and structural studies on di-oxovanadium(V) complexes of $N(4)$-substituted pyrazole based thiosemicarbazones
}

\author{
Arijit Hazra ${ }^{\text {a }}$, Anil Kumar Barik ${ }^{\mathrm{b}}$, Sachindranath Pal ${ }^{\mathrm{c}}$, Samik Gupta ${ }^{\mathrm{a}}$, Somnath Roy ${ }^{\mathrm{a}}$, \\ Ray J. Butcher ${ }^{\mathrm{d}}$, Shie-Ming Peng ${ }^{\mathrm{e}}$, G.H. Lee ${ }^{\mathrm{e}}$, Susanta Kumar Kar ${ }^{\mathrm{a}, *}$ \\ a Department of Chemistry, University College of Science, 92, Acharya Prafulla Chandra Road, Calcutta 700 009, West Bengal, India \\ ${ }^{\mathrm{b}}$ Department of Chemistry, St. Paul's C.M. College, 33/1, Raja Rammohan Roy Sarani, Calcutta 700 009, India \\ ${ }^{\mathrm{c}}$ Department of Chemistry, Sree Chaitanya College, Habra, North 24 Parganas, West Bengal, India \\ d Department of Chemistry, Howard University, 2400 Sixth Street, N.W., Washington, DC 200 59, USA \\ ${ }^{\mathrm{e}}$ Department of Chemistry, National Taiwan University, Taipei 106, Taiwan, ROC
}

Received 9 August 2006; accepted 5 September 2006

Available online 22 September 2006

\begin{abstract}
Three mononuclear cis-dioxovanadium(V) complexes of tridentate thiosemicarbazones derived from 5-methyl-3-formylpyrazole (MPA) and N(4)-methyl/ethyl/dimethyl thiosemicarbazide have been synthesized and characterized. Single crystal X-ray analyses were performed with $\left[\mathrm{VO}_{2} \mathrm{~L}^{1}\right](\mathbf{1}),\left[\mathrm{VO}_{2} \mathrm{~L}^{2}\right](\mathbf{2})$ and $\left[\mathrm{VO}_{2} \mathrm{~L}^{3}\right](\mathbf{3})$, where $\mathrm{L}^{1}, \mathrm{~L}^{2}$ and $\mathrm{L}^{3}$ denote the $[1+1]$ thiosemicarbazone mono-anions derived from MPA and N(4)-substituted methyl/ethyl/dimethyl thiosemicarbazide respectively. In all the complexes the vanadium atom is in a distorted square pyramidal geometry with a $\mathrm{N}_{2} \mathrm{SO}_{2}$ chromophore. The interesting finding in the work is that in complexes $\mathbf{1}$ and $\mathbf{2}$, the thioimine nitrogen unusually participates in coordination whereas in $\mathbf{3}$ it is the azomethine nitrogen (quite usual) which is involved in the coordination process.
\end{abstract}

(C) 2006 Elsevier Ltd. All rights reserved.

Keywords: Vanadium(V); Spectral properties; Crystal structure; Co-crystals; 5-Methyl-3-formyl-N(4)-methyl/ethyl/dimethyl thiosemicarbazones

\section{Introduction}

The coordination chemistry of vanadium is of great current interest because of the discovery of its presence in abiotic as well as biotic systems. The element is present in some sea squirts $[1,2]$; mushrooms $[3,4]$ and vanadium containing enzymes such as nitrogenase [5] and haloperoxidases [6], etc. Vanadium $(\mathrm{V})$ complexes are known as potent inhibitors of various enzymes. Another important impetus to the coordination chemistry of vanadium in the context of medical applications has arisen from the ability of vanadium complexes to promote the insulin mimetic

\footnotetext{
* Corresponding author. Tel.: +91 33 24322936; fax: +91 3323519755. E-mail address: skkar_cu@yahoo.co.in (S.K. Kar).
}

activity in pathophysiological state of diabetes mellitus in humans [7-10]. This biological and catalytic relevance of vanadium has prompted the synthesis of numerous model vanadium compounds containing $\mathrm{O}, \mathrm{N}$ donor ligands, whose spectroscopic, magnetic and redox properties have been widely investigated [11-21]. Some other vanadium complexes of $\mathrm{O}, \mathrm{N}$ donor ligands have been reported in recent times [22]. Although a volume of work has enriched the vanadium chemistry dealing with heterocyclic thiosemicarbazones [23], up until now, little research has centered on vanadium chemistry with thiosemicarbazones having pyrazole as the heterocyclic part. Therefore, considering the broad spectrum of potentially useful biological implications and the catalytic activity of the metal ion complexes with 5-methyl-3-formyl pyrazole thiosemicarbazones, this communication reports the synthesis, spectroscopic and 
X-ray crystallographic characterization of three dioxovanadium(V) complexes with 5-methyl-3-formylpyrazole$N$ (4)-methyl/ethyl/dimethyl thiosemicarbazones $\mathrm{HL}^{1}, \mathrm{HL}^{2}$ and $\mathrm{HL}^{3}$ respectively. We have reported earlier the synthesis and coordinating behaviour of $\mathrm{HL}^{1}$ towards the $\mathrm{Ni}(\mathrm{II})$ ion [24]. As an extension of the work, we have used the same ligand $\left(\mathrm{HL}^{1}\right)$ along with two other similar ligands to study dioxovanadium chemistry in a NNS donor environment. In our previous work [24], we have noticed that the tridentate ligand, $\mathrm{HL}^{1}$ out of two neighbouring nitrogen atoms - the azomethine and the thioimine - utilizes the azomethine one as one of the donor sites. This common observation is also extensively reported by other authors $[23,25]$ engaged in studies on the coordination behaviour of heterocyclic thiosemicarbazone ligands towards transition metal ions. The peculiarity of this work is that instead of the azomethine nitrogen the unexpected thioimine nitrogen exhibits coordination in $\mathrm{HL}^{1}$ and $\mathrm{HL}^{2}$, whereas $\mathrm{HL}^{3}$ behaves as usual utilizing its azomethine nitrogen as one of the donor atoms. This is quite a novel observation.

\section{Experimental}

\subsection{Reagents and starting materials}

Solvents and reagents were obtained from commercial sources and used without further purification unless otherwise stated. N(4)-Methyl-3-thiosemicarbazide; N(4)-ethyl3-thiosemicarbazide; N(4)-dimethyl-3-thiosemicarbazide were purchased from Aldrich Chemicals, USA. Ethanol was purified using the established method [26].

\subsection{Preparation of the ligands $H L^{1}, H L^{2}, H L^{3}$}

All three ligands were synthesized following the same method as reported earlier for $\mathrm{HL}^{1}$ [24]. N(4)-Ethyl-3-thiosemicarbazide and $N(4)$-dimethyl-3-thiosemicarbazide were used instead of $N(4)$-methyl-3-thiosemicarbazide for $\mathrm{HL}^{2}$ and $\mathrm{HL}^{3}$ respectively.

$\mathrm{HL}^{1}$ : Yield: $\sim 70 \%$; mp: $201{ }^{\circ} \mathrm{C}$; CHN: (Found: C, 43.54; $\mathrm{H}, 5.82 ; \mathrm{N}, 34.69 \%$. Calculated for $\mathrm{C}_{7} \mathrm{H}_{11} \mathrm{~N}_{5} \mathrm{~S}: \mathrm{C}, 42.63 ; \mathrm{H}$, $5.59 ; \mathrm{N}, 35.53) ; v_{\max } / \mathrm{cm}^{-1} 3300,3190,1620,1565,1040$, $865 ;{ }^{1} \mathrm{H}$ NMR $\delta\left(d_{6}\right.$-DMSO) $2.26(3 \mathrm{H}, \mathrm{s}), 2.85(3 \mathrm{H}, \mathrm{d})$, $6.34(1 \mathrm{H}, \mathrm{s}), 7.95(1 \mathrm{H}, \mathrm{s}), 8.50(1 \mathrm{H}, \mathrm{s}), 11.32(1 \mathrm{H}, \mathrm{s})$; $m / z=197\left(\mathbf{M}^{+}, 100 \%\right)$.

$\mathrm{HL}^{2}$ : Yield: $\sim 67 \%$; mp: $194{ }^{\circ} \mathrm{C}$; $\mathrm{CHN}$ : (Found: C, 46.55; $\mathrm{H}, 5.97 ; \mathrm{N}, 32.86 \%$. Calculated for $\mathrm{C}_{8} \mathrm{H}_{13} \mathrm{~N}_{5} \mathrm{~S}: \mathrm{C}, 45.49 ; \mathrm{H}$, 6.16 ; N, 33.17) $v_{\max } / \mathrm{cm}^{-1} 3300-3210,1622,1538,1027$, $837 ;{ }^{1} \mathrm{H}$ NMR $\delta\left(d_{6}\right.$-DMSO) $1.06(3 \mathrm{H}, \mathrm{t}), 2.20(3 \mathrm{H}, \mathrm{s})$, $3.21(2 \mathrm{H}, \mathrm{m}), 6.33(1 \mathrm{H}, \mathrm{s}), 7.61(1 \mathrm{H}, \mathrm{s}), 11.28(1 \mathrm{H}, \mathrm{s})$; $m / z=211\left(\mathbf{M}^{+}, 53 \%\right)$.

$\mathrm{HL}^{3}$ : Yield: $\sim 69 \%$; mp: $194{ }^{\circ} \mathrm{C}$; CHN: (Found: C, 46.55; $\mathrm{H}, 5.97 ; \mathrm{N}, 32.86 \%$. Calculated for $\mathrm{C}_{8} \mathrm{H}_{13} \mathrm{~N}_{5} \mathrm{~S}: \mathrm{C}, 45.49 ; \mathrm{H}$, 6.16 ; N, 33.17). $v_{\max } / \mathrm{cm}^{-1} 3300-3200,1611,1024,865 ;{ }^{1} \mathrm{H}$ NMR $\delta\left(d_{6}\right.$-DMSO $) 2.25(3 \mathrm{H}, \mathrm{s}), 3.08(6 \mathrm{H}, \mathrm{s}), 6.24(1 \mathrm{H}, \mathrm{s})$, $8.06(1 \mathrm{H}, \mathrm{s}), 10.79(1 \mathrm{H}, \mathrm{s}) ; m / z=211\left(\mathrm{M}^{+}, 82 \%\right)$.

\subsection{Preparation of the complexes}

\subsubsection{Preparation of complex 1}

To a solution of $\mathrm{HL}^{1}(0.447 \mathrm{~g}, 2.27 \mathrm{mmol})$ in hot purified ethanol $\left(15 \mathrm{~cm}^{3}\right)$ was added $\mathrm{VO}(\mathrm{acac})_{2}(0.601 \mathrm{~g}$, $2.27 \mathrm{mmol}$ ). The green mixture was refluxed for $3 \mathrm{~h}$ at water bath temperature, within which time the mixture turned greenish yellow. This mixture was kept at room temperature for slow evaporation. The yellow crystals so formed were filtered off after $72 \mathrm{~h}$, washed with ethanol:water $(1: 1 \mathrm{v} / \mathrm{v})$ and dried over anhydrous $\mathrm{CaCl}_{2}$. Yield ca. $76 \%$. Yellow crystals of complex 1, suitable for X-ray diffraction studies were grown by slow evaporation of an ethanolic solution at room temperature.

\subsubsection{Preparation of the complexes $\mathbf{2}$ and $\mathbf{3}$}

These two complexes were prepared using a similar method as described for 1 employing $\mathrm{HL}^{2}$ and $\mathrm{HL}^{3}$ as the ligand respectively. Yields ca. $72 \%$ (for 2) and ca. $69 \%$ (for 3). Pale yellow crystals of 2 and deep orange crystals of 3 suitable for X-ray crystallographic studies were isolated by slow evaporation of an ethanolic solution of the complexes at room temperature.

\subsection{Physical measurements}

Carbon, hydrogen and nitrogen contents of the ligands $\mathrm{HL}^{1}, \mathrm{HL}^{2}$ and $\mathrm{HL}^{3}$ and of the $\mathrm{V}(\mathrm{V})$ complexes were determined with a Perkin-Elmer CHNS/O analyzer 2400 at IACS, Kolkata. The molar conductance values of the complexes were measured in DMF solution with a Systronic Model 304 digital conductivity meter. The electronic spectra of the complexes in acetonitrile solution and the diffuse reflectance spectra of the complexes were recorded on a Hitachi model U-3501 spectrophotometer. IR spectra were recorded on a Perkin-Elmer model 883 infrared spectrophotometer. ${ }^{1} \mathrm{H}$ NMR spectra of the aldehyde and the ligands were recorded in $d_{6}$-DMSO with a Bruker AM $300 \mathrm{~L}(300 \mathrm{MHz})$ superconducting FTNMR. Mass spectra of the ligands were done with JEOLJMS-AX 500 mass spectrometer. Cyclic voltammetry was carried out using Sycopel model AEW2 $1820 \mathrm{~F} / \mathrm{S}$ instrument. The measurements were performed at $300 \mathrm{~K}$ in acetonitrile solution containing $0.2 \mathrm{M}$ TEAP as the supporting electrolyte and $10^{-3}-10^{-4} \mathrm{M}$ of the $\mathrm{V}(\mathrm{V})$ complexes, deoxygenated by bubbling with nitrogen. The working, counter and reference electrodes used were a platinum wire, a platinum coil and an SCE.

\subsection{Crystallographic measurements}

A summary of crystallographic data is given in Table 1 . Complete tabulations of crystallographic data, bond lengths and angles, atomic coordinates, thermal parameters and completely labelled ball and stick diagrams are available as supporting information. Data were obtained using a Bruker SMART diffractometer at 293(2) K (for 1), 93(2) K (for 2) and 295(2) K (for 3). Unit cell dimensions 
Table 1

Experimental data for the crystallographic analysis

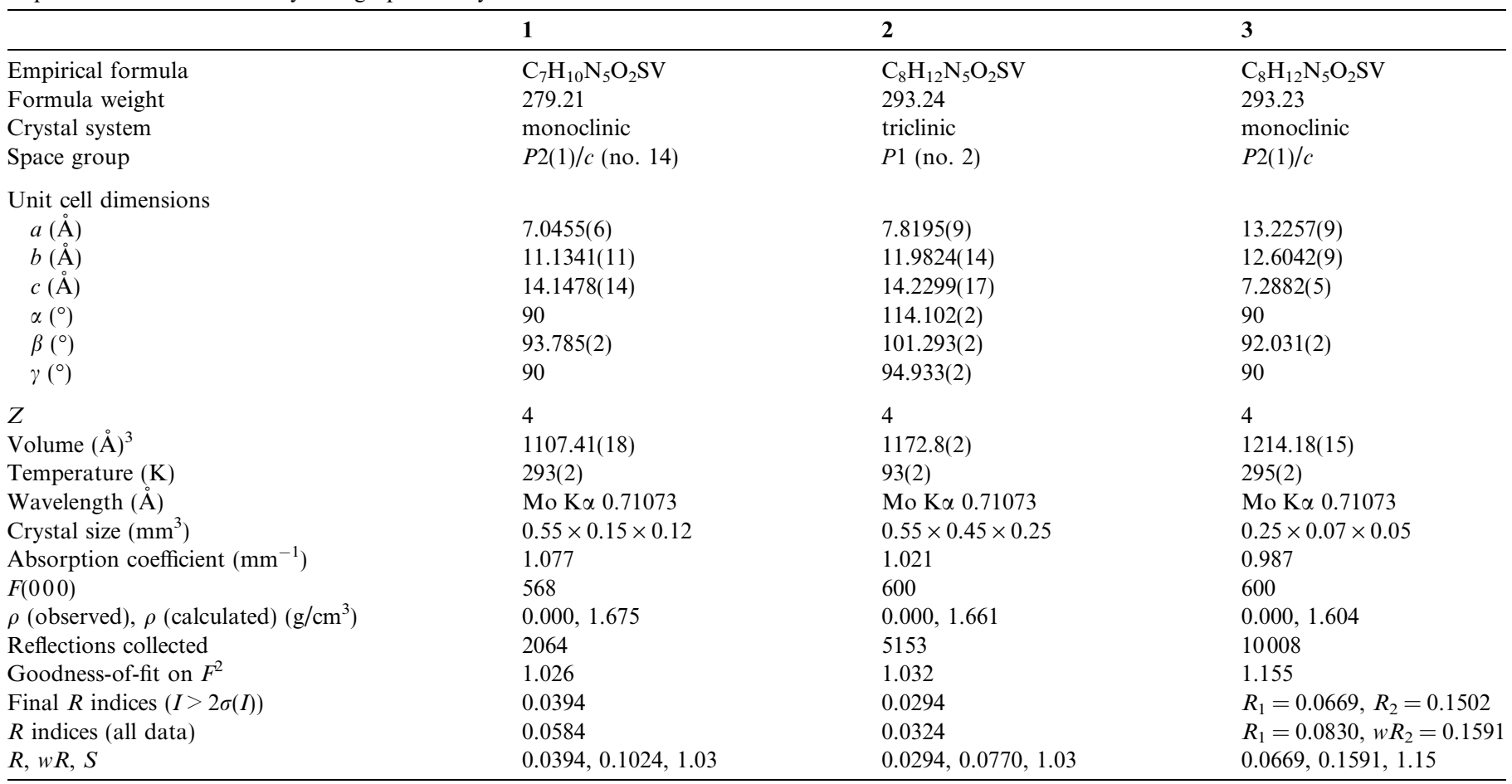

were refined by use of the settings of 25 accurately determined reflections, widely separated in reciprocal space. Intensities were measured by $\omega$-scans. A total of 2064 reflections for $\mathbf{1}, 5153$ reflections for $\mathbf{2}$ and 10008 reflections for $\mathbf{3}$ were collected. The data were averaged ( $R_{\text {int }}=0.031 \%$ for complex $\mathbf{1}, R_{\text {int }}=0.0 \%$ for complex 2 and $R_{\text {int }}=0.0454 \%$ for complex 3 ). The structures were solved by direct methods and subsequent Fourier syntheses were used to determine the remaining non-hydrogen atomic positions.

Intensities were collected for Lorentz and polarization effects, and empirical absorption corrections were applied based on a set of $\psi$-scans. Calculations for $\mathbf{1}$ and $\mathbf{2}$ were carried out using Bruker SHELXTL and Bruker SAINT for $\mathbf{3}$ (data reduction), SHELXL-97 (absorption correction, structure solution or refinement and molecular graphics). The structures were solved using direct methods and refined on $F^{2}$ using full matrix least squares techniques with anisotropic displacement factors for all non-hydrogen atoms. Positions of the hydrogen atoms were calculated from the geometry of the molecular skeleton and their thermal displacement parameters were refined isotropically on a group-wise basis. Selected bond lengths and angles are reported in Table 3. H-Bonding distances and angles are shown in Tables $3 \mathrm{a}$ and $\mathrm{b}$.

\section{Results and discussion}

\subsection{Characterization of the ligands $H L^{1}, H L^{2}$ and $H L^{3}$}

The elemental analyses $(\mathrm{C}, \mathrm{H}$ and $\mathrm{N})$ and IR spectral data [characteristic bands $\left(\mathrm{cm}^{-1}\right)$ at $3300-3260\left(v_{\mathrm{NH}}\right)$,
$\left.1575\left(v_{\mathrm{CH}=\mathrm{N}}\right), 1095\left(v_{\mathrm{N}-\mathrm{Pz}}\right), 1000\left(v_{\mathrm{C}=\mathrm{S}}\right)\right]$ are in good agreement with the structures in Fig. 1. The absence of any band in the $2600-2200 \mathrm{~cm}^{-1}$ region of the IR spectra of the free ligands suggests the absence of any thiol tautomer in the solid state $[27,28]$.

\section{2. ${ }^{1} H$ NMR spectra of the ligands}

The ${ }^{1} \mathrm{H}$ NMR spectra $\left(\delta_{\mathrm{H}} \mathrm{ppm}\right)$ in $d_{6}$-DMSO at $300 \mathrm{MHz}$ of the ligand $\mathrm{HL}^{1}, \mathrm{HL}^{2}$ and $\mathrm{HL}^{3}$ give singlets at $\delta 2.26(3 \mathrm{H}), \delta 2.20(3 \mathrm{H})$ and $\delta 2.25(3 \mathrm{H})$ assignable to $\mathrm{C}_{5}-\mathrm{CH}_{3}$ (ring pz) and singlets at $\delta 6.34(1 \mathrm{H}), \delta 6.33(1 \mathrm{H})$ and $\delta 6.24(1 \mathrm{H})$ due to $\mathrm{C}_{4}-\mathrm{H}$ (ring pz) respectively. A narrow split doublet at $\delta 2.85(J=6 \mathrm{~Hz}, 3 \mathrm{H})$ for $\mathrm{HL}^{1}$ is ascribed to the terminal $\mathrm{N}-\mathrm{CH}_{3}$; a narrow-split multiplet at $\delta 3.21(2 \mathrm{H})$ and triplet at $\delta 1.06(J=6.5 \mathrm{~Hz}, 3 \mathrm{H})$ for $\mathrm{HL}^{2}$ are ascribed to terminal $\mathrm{NCH}_{2} \mathrm{CH}_{3}$ and $\mathrm{NCH}_{2} \mathrm{CH}_{3}$ respectively and a singlet at $\delta 3.08(6 \mathrm{H})$ for $\mathrm{HL}^{3}$ is ascribed

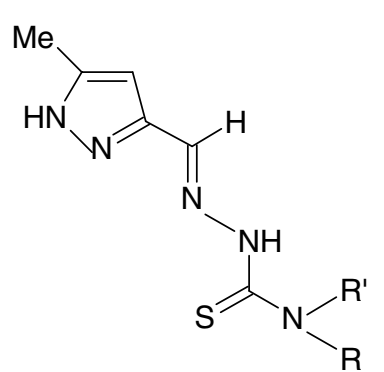<smiles></smiles>

Fig. 1. Structure of the ligands: $\mathrm{R}=\mathrm{Me}, \mathrm{R}^{\prime}=\mathrm{H}$ in $\mathrm{HL}^{1} ; \mathrm{R}=\mathrm{Et}, \mathrm{R}^{\prime}=\mathrm{H}$ in $\mathrm{HL}^{2} ; \mathrm{R}=\mathrm{Me}, \mathrm{R}^{\prime}=\mathrm{Me}$ in $\mathrm{HL}^{3}$. 
to terminal $\mathrm{N}\left(\mathrm{CH}_{3}\right)_{2}$. A slightly broad singlet at $\delta 7.95(1 \mathrm{H})$ for $\mathrm{HL}^{1}$, at $\delta 7.61(1 \mathrm{H})$ for $\mathrm{HL}^{2}$ and a singlet at $\delta 8.06(1 \mathrm{H})$ for $\mathrm{HL}^{3}$ are ascribed to the azomethine proton of the ligand. A singlet at $\delta 11.32(1 \mathrm{H})$ for $\mathrm{HL}^{1}$, at $\delta 11.28(1 \mathrm{H})$ for $\mathrm{HL}^{2}$ and at $\delta 10.79(1 \mathrm{H})$ for $\mathrm{HL}^{3}$ confirm the presence of azomethine $\mathrm{NH}$ in all three ligands.

\subsection{Characterization of the complex species}

The $\mathrm{V}(\mathrm{V})$ complexes have been prepared employing a $\mathrm{V}(\mathrm{IV})$ starting material such as $\mathrm{VO}(\mathrm{acac})_{2}$. Molecular dioxygen from air serves as the oxidant during the course of the reaction. All the complexes gave satisfactory $\mathrm{C}, \mathrm{H}$, $\mathrm{N}$ analyses (Table 2) and are diamagnetic in nature. The molar conductance values of the complexes in DMF classify them as non-electrolytes [29].

\subsubsection{IR spectra of the complexes}

A comparative study of the IR spectral data of the reported complexes with those of the uncomplexed ligand gives meaningful information regarding bonding sites of the ligand molecules. The IR spectra of the complexes show a broad band spanning in the $3400-2900 \mathrm{~cm}^{-1}$ region, probably arising from the $\mathrm{H}$-bonding between one of the $\mathrm{V}=\mathrm{O}$ groups with one pyrazole $\mathrm{N}$ atom. The IR band appearing at $1573 \mathrm{~cm}^{-1}$ in the free ligand $\mathrm{HL}^{1}, \mathrm{HL}^{2}, \mathrm{HL}^{3}$ spectra $(\mathrm{CH}=\mathrm{N})$ has been observed to shift towards a lower wavenumber by $25-30 \mathrm{~cm}^{-1}$ in the IR spectra of $1,15-20 \mathrm{~cm}^{-1}$ for 2 and by $35-40 \mathrm{~cm}^{-1}$ for 3 , due to involvement of the azomethine nitrogen [30] in bonding. In addition, a strong two-band pattern in the $960-840 \mathrm{~cm}^{-1}$ region is the signature of the cis-dioxovanadium(V) moiety [31] which may be assigned to symmetric and asymmetric $v(\mathrm{O}=\mathrm{V}=\mathrm{O})$ vibrations of the $c i s-\mathrm{VO}_{2}$ group [32].

An intense strong band at ca. $850 \mathrm{~cm}^{-1}$ characteristic for $v_{\mathrm{C}}=\mathrm{s}$ in all three ligands are found to suffer downfield shifts (ca. $80-100 \mathrm{~cm}^{-1}$ ) after complexation in all the complexes. This indicates that the sulfur atom of the $\mathrm{C}=\mathrm{S}$ in its deprotonated thiol form functions as the coordination site [30].

\subsubsection{Solution spectra of the complexes}

A DMF solution of the complexes record spectral data around $34364 \mathrm{~cm}^{-1}$ for $\mathbf{1}, 34350 \mathrm{~cm}^{-1}$ for 2 and two bands, one around $33350 \mathrm{~cm}^{-1}$ and the other around $24250 \mathrm{~cm}^{-1}$, for 3 . Thus for all the complexes, the intense absorption band around $34000 \mathrm{~cm}^{-1}$ corresponds to an intraligand transition whereas the additional band for 3 around $24250 \mathrm{~cm}^{-1}$ is assignable to a $\mathrm{L}-\mathrm{V}(\mathrm{d} \pi)$ LMCT band [33].

\subsection{3. ${ }^{1} H$ NMR spectra of the Complexes}

The ${ }^{1} \mathrm{H}$ NMR spectral data $(\delta \mathrm{ppm})$ of $\mathbf{1}-\mathbf{3}$ in $d_{6}$-DMSO at $300 \mathrm{MHz}$ give singlets at $\delta 2.32(3 \mathrm{H}), 2.32(3 \mathrm{H})$ and $\delta$ $2.30(3 \mathrm{H})$ assignable to $\mathrm{C}_{5}-\mathrm{CH}_{3}$ (Ring $\mathrm{Pz}$ ) and singlets at $\delta 6.66(1 \mathrm{H}), \delta 6.66(1 \mathrm{H})$ and $\delta 6.63(1 \mathrm{H})$ ascribed to $\mathrm{C}_{4}$ $H$ (Ring Pz) respectively. A narrow split doublet at $\delta$ $2.95(J=6 \mathrm{~Hz}, 3 \mathrm{H})$ for $\mathbf{1}$ is ascribed to the terminal $\mathrm{NCH}_{3}$, a narrow split multiplet at $\delta 3.43(2 \mathrm{H})$ and triplet at $\delta 1.18(J=6.5 \mathrm{~Hz}, 3 \mathrm{H})$ for 2 are ascribed to terminal $\mathrm{NCH}_{2} \mathrm{CH}_{3}$ and $\mathrm{NCH}_{2} \mathrm{CH}_{3}$ respectively, a narrow split singlet at $\delta 3.26(6 \mathrm{H})$ for 3 is ascribed to the terminal $\mathrm{N}\left(\mathrm{CH}_{3}\right)_{2}$. A slightly broad singlet at $\delta 8.15(1 \mathrm{H})$ in $\mathbf{1}$, at $\delta 7.73(1 \mathrm{H})$ in 2 and appearance of a singlet at $\delta 8.46$ $(1 \mathrm{H})$ in 3 is ascribed to the azomethine proton. Thus although the azomethine $\mathrm{CH}$ proton appears downfield (compared to the corresponding free ligand) in all the complexes, that in $\mathbf{3}$ undergoes the maximum downfield shift. This indicates that in $\mathbf{3}$ the $\mathrm{CH}$ azomethine proton, being nearby to the azomethine nitrogen donor center, feels maximum reduction in electron density. In $\mathbf{1}$ and $\mathbf{2}$ the azomethine $\mathrm{CH}$ proton is quite far from the thioimine nitrogen donor center and hence causes less reduction in electron density around $\mathrm{CH}$. The absence of a singlet around $\delta$ 11.3 in $\mathbf{1}, \delta 11.1$ in $\mathbf{2}$ and $\delta 10.8$ in $\mathbf{3}$ confirms the enethiolization process prior to complexation followed by deprotonation during complexation. This is also evident from the X-ray crystal structure studies.

\subsubsection{Electrochemistry}

Cyclic voltammograms of $\mathbf{1}$ and $\mathbf{3}$ were measured in acetonitrile within the potential window +0.20 to $-1.5 \mathrm{~V}$. The complexes display irreversible single step one electron responses around $-0.78 \mathrm{~V}$ vs. SCE corresponding to $\mathrm{V}(\mathrm{V}) / \mathrm{V}(\mathrm{IV})$ reduction. The electrochemical study of $\mathbf{2}$ could not be performed because of its very poor solubility in the said solvent.

\subsubsection{Structure description}

The molecular structures of $\mathbf{1}-\mathbf{3}$, including the atom labelling, are shown in Fig. 3a-c respectively (atom labels of 2 appear in lower case in Fig. 3b). Their selected bond lengths and angles are given in Table $3 \mathrm{a}$ and $\mathrm{b}$. The $\left[\mathrm{VO}_{2} \mathrm{~L}^{x}\right], x=1-3$ unit of the complexes is neutral and mononuclear. In each complex, the unit cell comprises of four molecules. The $\mathrm{V}$ atom in each complex is coordinated

Table 2

Analytical data and pertinent physico-chemical properties of the complexes

\begin{tabular}{llllll}
\hline Complex & Colour & $\% \mathrm{C}$ & $\% \mathrm{H}$ & $\% \mathrm{~N}$ & $\Lambda_{\mathrm{M}} \Omega^{-1} \mathrm{~cm}^{2} \mathrm{~mol}^{-1}\left(\mathrm{in} \mathrm{DMF}^{\mathrm{D}}\right.$ \\
\hline$\left[\mathrm{VO}_{2} \mathrm{~L}^{1}\right]$ & pale yellow & $30.08(30.11)$ & $3.58(3.59)$ & $25.07(25.09)$ & 31 \\
{$\left[\mathrm{VO}_{2} \mathrm{~L}^{2}\right]$} & yellow & $32.76(33.01)$ & $4.09(4.15)$ & $23.89(24.25)$ & 35 \\
{$\left[\mathrm{VO}_{2} \mathrm{~L}^{3}\right]$} & yellow & $32.76(33.01)$ & $4.09(4.15)$ & $23.89(24.25)$ & 34 \\
\hline
\end{tabular}

Elemental analyses found (calc.). 
to two nitrogen atoms, one thiolato sulfur and two terminal oxo groups. Out of the two nitrogen donor atoms, the pyrazolyl nitrogen is common in all the cases. The other nitrogen is the thioimine ( $\mathrm{N} 1$ for $1, \mathrm{~N} 2 \mathrm{~A} / 2 \mathrm{~B}$ for 2 ) and the azomethine ( $\mathrm{N} 3$ for 3 ) one.

The thiosemicarbazone molecule functions as singly deprotonated tridentate ligand. The deprotonation is accompanied by tautomerization to the iminothiolate form. The coordination geometry around the $\mathrm{V}$ atom in all the three complexes is best described as square pyramidal with a slight distortion towards a trigonal bipyramidal geometry. The Schiff base ligand is coordinated meridionally, occupying the three equatorial positions. The remaining equatorial position is occupied by one of the two oxo groups $(\mathrm{O} 2)$. The apical position is satisfied by another oxo group $(\mathrm{O} 1)$. The $\tau$ parameters of the complexes ( 0.20 for $\mathbf{1}, 0.18$ for $\mathbf{2}$ (unit-A), 0.26 for $\mathbf{2}$ (unit-B) and 0.14 for 3 ) also support their square pyramidal geometry. [34,35] The maximum distortion toward trigonal bipyramidal geometry occurs in $\mathbf{2}$ (unit-B). All the bond angles comprising the adjacent donor atoms in the basal plane and $\mathrm{V}$ as well as any one donor atom, $\mathrm{V}$ and $\mathrm{O} 1$ i.e., $\mathrm{O}_{1} \mathrm{VO}_{2}, \mathrm{SVO}_{1}, \mathrm{~N}_{1} \mathrm{VO}_{1}$ (for 1, 2), $\mathrm{N}_{2} \mathrm{VO}_{1}$ (for 3), $\mathrm{N}_{3} \mathrm{VO}_{1}$ (for 1, 3) and $\mathrm{N}_{2} \mathrm{VO}_{1}$ (for 2) are increased from the ideal value of $90^{\circ}$ (Table $3 \mathrm{~b}$ ) because of the shifting of the Vatom from the square plane toward the apical oxygen $(\mathrm{O} 1)$. The $\mathrm{V}$-atom is shifted from the square plane upward through a distance of $0.560 \AA$ in $1,0.569 \AA$ in 2 (unit-A), $0.568 \AA$ in 2 (unit-B) and $0.559 \AA$ in 3 .

The average $\mathrm{V}=\mathrm{O}$ distances $1.623 \AA$ in $\mathbf{1}, 1.632 \AA$ in $\mathbf{2}$ and $1.614 \AA$ in 3 , being slightly longer than the normal $\mathrm{V}=\mathrm{O}$ double bond length of $1.595 \AA$, indicate that the oxygens are involved in weak hydrogen bonding interactions [36]. The $\mathrm{V}-\mathrm{N}(1)$ and $\mathrm{V}-\mathrm{N}(3)$ distances 2.055 and $2.048 \AA$ in $1, \mathrm{~V}-\mathrm{N}(2 \mathrm{~A})$ and $\mathrm{V}-\mathrm{N}(1 \mathrm{~A})$ distances 2.071 and $2.050 \AA$ in $2, \mathrm{~V}-\mathrm{N}(3)$ and $\mathrm{V}-\mathrm{N}(2)$ distances 2.184 and $2.043 \AA$ in 3 are in accordance with literature values for $\mathrm{V}-\mathrm{N}$ distances [36,37].

The asymmetric unit in $\mathbf{2}$ contains two independent molecules; however, there are conformational differences between them. The vanadium atoms, being separated by a distance of $5.515 \AA$ in the two units $\mathrm{A}$ and $\mathrm{B}$, are
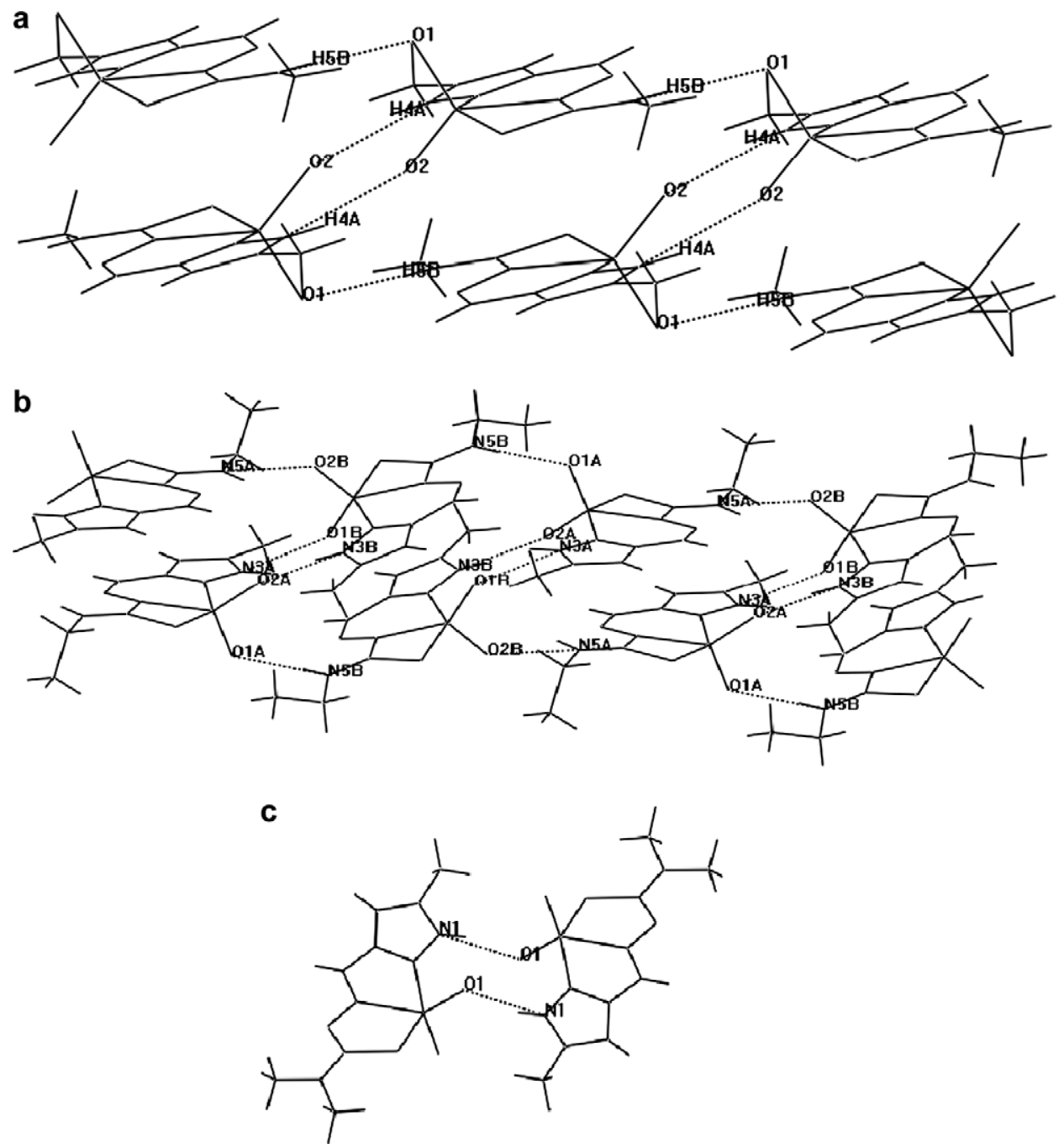

Fig. 2. (a) H-bonding in 1; (b) H-bonding in 2; (c) H-bonding in 3. 

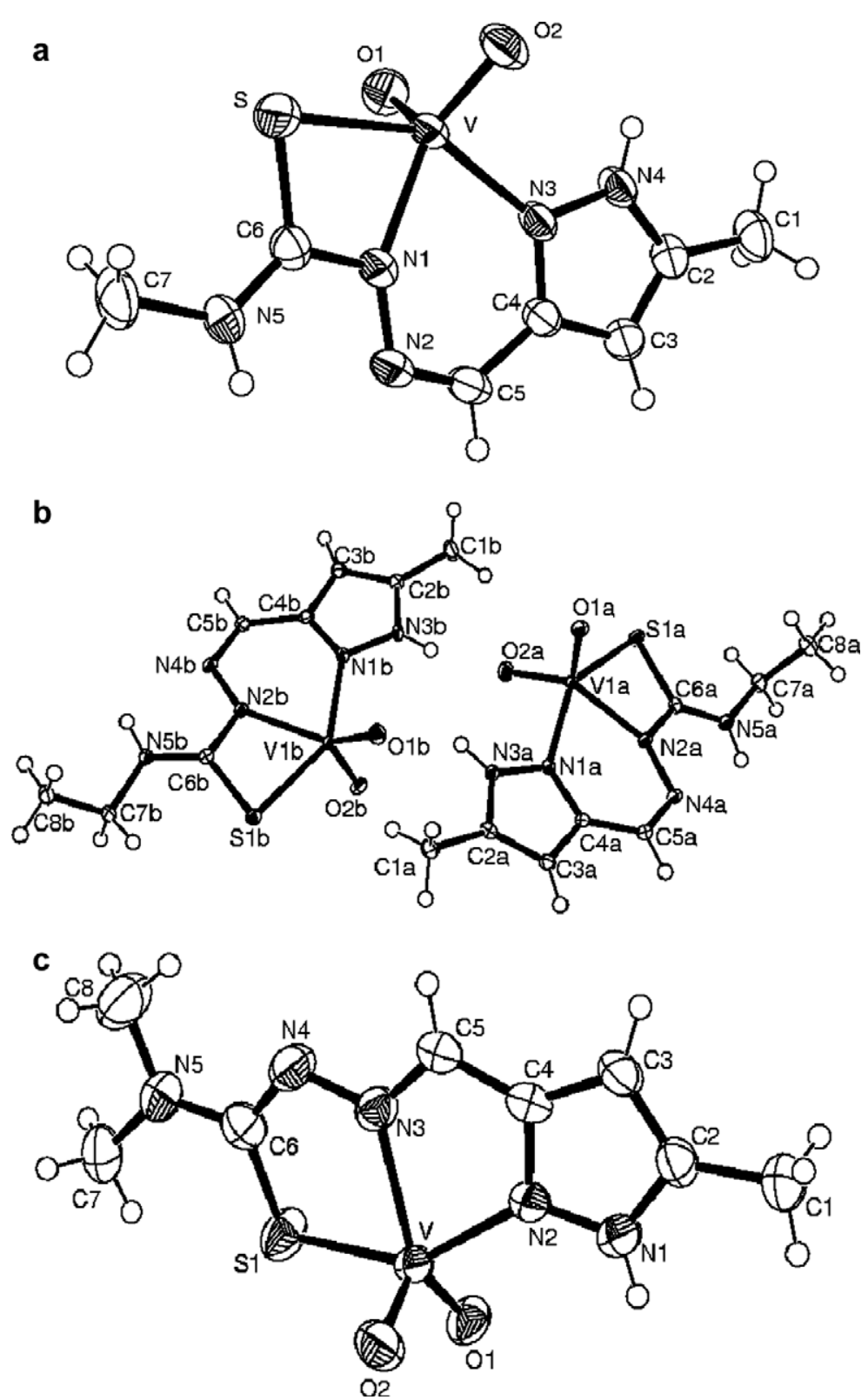

Fig. 3. (a) Molecular structure and atom-numbering scheme for $\mathbf{1}$ with thermal ellipsoids drawn at the 50\% probability level; (b) molecular structure and atom-numbering scheme for $\mathbf{2}$ with thermal ellipsoids drawn at the $50 \%$ probability level. Two equivalent molecules in the asymmetric units, A and B are shown; (c) molecular structure and atom-numbering scheme for $\mathbf{3}$ with thermal ellipsoids drawn at the $50 \%$ probability level.

deviated downward by $0.315 \AA$ and upward by $0.240 \AA$ from the mean plane forming a skew conformation at $\mathrm{C} 1 \mathrm{~B}$ and $\mathrm{C} 8 \mathrm{~B}$ and eclipsed at $\mathrm{C} 1 \mathrm{~A}$ and $\mathrm{C} 7 \mathrm{~A}$. The units $\mathrm{A}$ and $\mathrm{B}$ are joined by weak intermolecular hydrogen bonding.

In case of 1, C1, C2, C3, C4, N3, N4, C5, N2, N1, C6, S are roughly in the same plane (with a maximal deviation of $0.063 \AA$ ) with the vanadium atom shifted by $0.317 \AA$ out of that plane towards O1 [32]. Due to that latter deviation the conformation of the six-membered chelate ring containing $\mathrm{V}, \mathrm{N} 3 \mathrm{C} 4, \mathrm{C} 5, \mathrm{~N} 2$ and $\mathrm{N} 1$ atoms is concluded to be an envelope at V. Cremer and Pople [38] puckering analysis shows that the four membered chelate ring containing $\mathrm{V}$, $\mathrm{N} 1, \mathrm{C} 6$ and $\mathrm{S}$ atoms also adopts an envelope conformation, but in that case on C6 (with a deviation of $0.111 \AA$ ) from the mean plane containing $\mathrm{V}, \mathrm{S}$ and $\mathrm{N} 1$ atoms.

In the case of $2, \mathrm{C} 1 \mathrm{~A} / 1 \mathrm{~B}, \mathrm{C} 2 \mathrm{~A} / 2 \mathrm{~B}, \mathrm{C} 3 \mathrm{~A} / 3 \mathrm{~B}, \mathrm{C} 4 \mathrm{~A} / 4 \mathrm{~B}$, $\mathrm{N} 1 \mathrm{~A} / 1 \mathrm{~B}, \mathrm{~N} 3 \mathrm{~A} / 3 \mathrm{~B}, \mathrm{C} 5 \mathrm{~A} / 5 \mathrm{~B}, \mathrm{~N} 4 \mathrm{~A} / 4 \mathrm{~B}, \mathrm{~N} 2 \mathrm{~A} / 2 \mathrm{~B}, \mathrm{C} 6 \mathrm{~A} / 6 \mathrm{~B}$ and $\mathrm{S} 1 \mathrm{~A} / 1 \mathrm{~B}$ [A for unit-A and $\mathrm{B}$ for unit-B] are roughly in the same plane [with a maximal deviation of $0.059 \AA$ for unit- $\mathrm{A}$ and $0.056 \AA$ for unit-B]. The vanadium atom is shifted upward by $0.315 \AA$ [for unit- $\mathrm{A}$ ]/downward by $0.242 \AA$ [for unit-B] out of that plane towards O1A (for unit-A)/O2B (for unit-B). Thus the six-membered chelate ring encompassing $\mathrm{V} 1 \mathrm{~A} / 1 \mathrm{~B}, \mathrm{~N} 1 \mathrm{~A} / 1 \mathrm{~B}, \mathrm{C} 4 \mathrm{~A} / 4 \mathrm{~B}, \mathrm{C} 5 \mathrm{~A} / 5 \mathrm{~B}$, $\mathrm{N} 4 \mathrm{~A} / 4 \mathrm{~B}$ and $\mathrm{N} 2 \mathrm{~A} / 2 \mathrm{~B}$ atoms is enveloped at the vanadium center in each case. Cremer and Pople [38] puckering analysis shows that the four membered chelate ring containing 
Table 3

Selected bond lengths $(\AA)$ and angles $\left(^{\circ}\right)$, with esds in parentheses

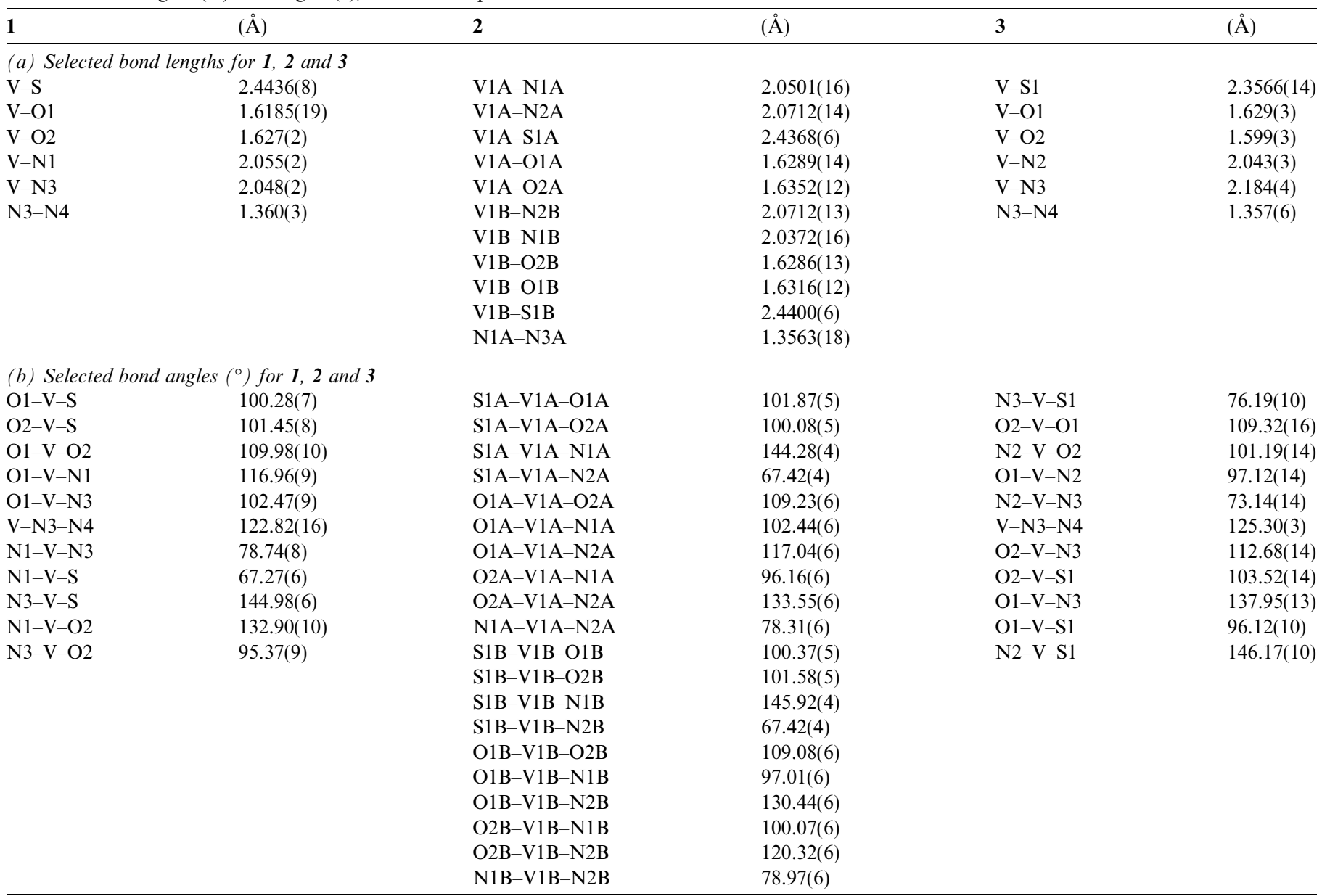

$\mathrm{V} 1 \mathrm{~A} / 1 \mathrm{~B}, \mathrm{~N} 2 \mathrm{~A} / 2 \mathrm{~B}, \mathrm{C} 6 \mathrm{~A} / 6 \mathrm{~B}$ and $\mathrm{S} 1 \mathrm{~A} / 1 \mathrm{~B}$ (unit-A and $\mathrm{B}$ ) also looks like an envelope on $\mathrm{C} 6$ (A and $\mathrm{B}$ ) with a deviation of $0.067 \AA$ (for unit- $\mathrm{A}) / 0.021 \AA$ (for unit-B) from the mean plane containing the $\mathrm{V} 1 \mathrm{~A} / 1 \mathrm{~B}, \mathrm{~S} 1 \mathrm{~A} / 1 \mathrm{~B}$ and $\mathrm{N} 2 \mathrm{~A} /$ $2 \mathrm{~B}$ atoms.

In the case of 3, C1, C2, C3, C4, N1, N2, C5, N3, N4, C6 and $\mathrm{S} 1$ are roughly in the same plane (with a maximal deviation of $0.200 \AA$ ) with the vanadium atom shifted by $0.354 \AA$ out of that plane towards O2. Because of this deviation, the conformation of the five-membered chelate ring containing $\mathrm{V}, \mathrm{C} 4, \mathrm{C} 5, \mathrm{~N} 3$ and $\mathrm{N} 2$ atoms is proposed to be an envelope at $\mathrm{V}$. The other five membered chelate ring containing $\mathrm{V}, \mathrm{N} 3, \mathrm{~N} 4, \mathrm{C} 6$ and $\mathrm{S} 1$ atoms is also in an envelope conformation on C6 (with a deviation of $0.204 \AA$ ) from the mean plane containing the $\mathrm{V}, \mathrm{N} 3, \mathrm{~N} 4$ and $\mathrm{S} 1$ atoms.

Complex $\mathbf{1}$ is stabilized through a network of weak $\mathrm{H}$-bond interactions (Fig. 2a). The details are presented in Table 4. The H-bond distances between $\mathrm{N} 3 \mathrm{~B}$ and $\mathrm{O} 2 \mathrm{~A}$ [2.708 $]$ and O1B and N3A [2.748 $]$ support a weakly Hbonded structure in 2 (Fig. 2b, Table 4). Similarly the Hbond distance between $\mathrm{N} 1$ and $\mathrm{O} 1$ in 3 is $2.77 \AA$, which also indicates the presence of weak H-bonding (Fig. 2c, Table 4).

Table 4

Details of hydrogen bond distances $(\AA)$ and angles $\left({ }^{\circ}\right)$

\begin{tabular}{|c|c|c|c|c|c|}
\hline Complex & $\mathrm{D}-\mathrm{H} \cdots \mathrm{A}$ & $d(\mathrm{D}-\mathrm{H})$ & $d(\mathrm{H} \cdots \mathrm{A})$ & $d(\mathrm{D} \cdots \mathrm{A})$ & $\angle(\mathrm{DHA})$ \\
\hline 1 & 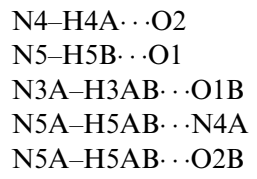 & $\begin{array}{l}0.8500 \\
0.8600 \\
0.8800 \\
0.8800 \\
0.8800\end{array}$ & $\begin{array}{l}1.97 \\
2.16 \\
2.00 \\
2.36 \\
2.11\end{array}$ & $\begin{array}{l}2.760(3) \\
2.980(3) \\
2.7477(18) \\
2.687(2) \\
2.837(2)\end{array}$ & $\begin{array}{l}151 \\
161 \\
141 \\
102 \\
140\end{array}$ \\
\hline 2 & $\begin{array}{l}\text { N3B-H3BB } \cdots \text { O2A } \\
\text { N5B-H5BB } \cdots \text { N4B } \\
\text { N5B-H5BB } \cdots \text { O1A }\end{array}$ & $\begin{array}{l}0.8800 \\
0.8800 \\
0.8800\end{array}$ & $\begin{array}{l}1.84 \\
2.41 \\
2.12\end{array}$ & $\begin{array}{l}2.7080(18) \\
2.705(2) \\
2.972(2)\end{array}$ & $\begin{array}{l}170 \\
100 \\
163\end{array}$ \\
\hline 3 & $\mathrm{~N} 1-\mathrm{H} 1 \mathrm{~A} \cdots \mathrm{O} 1$ & 0.8600 & 1.90 & $2.7722(4)$ & 160 \\
\hline
\end{tabular}




\section{Conclusion}

We have prepared three $\mathrm{V}(\mathrm{V})$ complexes employing $N(4)$-mono/disubstituted pyrazole derived thiosemicarbazone ligands. In the case of $N(4)$-monosubstituted $\left(\mathrm{HL}^{1}\right.$ and $\mathrm{HL}^{2}$ ) ligands, the unexpected thioimine nitrogen and not the expected azomethine nitrogen functions as one of the donor sites, whereas for the N(4)-disubstituted ligand $\left(\mathrm{HL}^{3}\right)$, the expected azomethine nitrogen acts as the donor site. The coordinating behaviour of similar types of N(4)substituted aldehydo thiosemicarbazone ligands so far reported, in general, establishes that it is the azomethine nitrogen which functions as one of the donor sites toward transition metal ions. This peculiar coordinating behaviour of the thioimine nitrogen is unique for these N(4)-monosubstituted pyrazole derived ligands toward V only.

\section{Acknowledgement}

One of the authors A.H thanks CSIR, India for awarding a JRF and S.K thanks for financial assistance.

\section{Appendix A. Supplementary material}

CCDC 617225,617226 and 617227 contain the supplementary crystallographic data for $\mathbf{1}, \mathbf{2}$ and $\mathbf{3}$. These data can be obtained free of charge via htpp://www.ccdc.cam. ac.uk/conts/retrieving.html, or from the Cambridge Crystallographic Data Centre, 12 Union Road, Cambridge CB2 1EZ, UK; fax: +44 1223-336-033; or e-mail: deposit@ ccdc.cam.ac.uk. Supplementary data associated with this article can be found, in the online version, at doi:10.1016/j.poly.2006.09.005.

\section{References}

[1] P. Frank, R.M.K. Carlson, E.J. Carlson, K.O.J. Hodgson, Inorg. Biochem. 94 (2003) 59-71.

[2] P. Frank, R.M.K. Carlson, E.J. Carlson, K.O. Hodgson, Coord. Chem. Rev. 237 (2003) 31-39.

[3] R.E. Berry, E.M. Armstrong, R.L. Beddoes, D. Collison, S.N. Ertok, M. Helliwell, C.D. Gamer, Angew. Chem., Int. Ed. 38 (1999) 795797.

[4] (a) K. Kanamori, Coord. Chem. Rev. 237 (2003) 147-161; (b) D. Rehder, Inorg. Chem. Commun. 6 (2003) 604-617.

[5] R.R. Eady, Coord. Chem. Rev. 237 (2003) 23-30, and references cited therein.

[6] (a) M. Weyand, H.J. Heeht, M. Kiess, M.F. Liaud, H. Vilter, D.J. Schomburg, Mol. Biol. 293 (1999) 595-611;

(b) J.N. Carter-Franklin, J.D. Parrish, R.A. Tehirret-Guth, R.D. Little, A. Butler, J. Am. Chem. Soc. 125 (2003) 3688-3689;

(c) D. Rehder, G. Santoni, G.M. Licini, C. Schulzke, B. Meier, Coord. Chem. Rev. 237 (2003) 53-63.

[7] (a) R.M. Brand, F.G. Hamel, Int. J. Pharm. 183 (1999) 117-123;

(b) P.G. Drake, B.I. Posner, Mol. Cell Biochem. 182 (1998) 79-89;

(c) P.G. Drake, A.P. Bevan, J.W. Burgess, J.J. Bergeron, B.I. Posner, Endocrinology 137 (1996) 4960-4968.

[8] (a) J.W. Eriksson, P. Lönnroth, B.I. Posner, A. Shaver, C. Wesslau, U.P. Smith, Diabetologia 39 (1996) 235-242;

(b) P.J. Stankiewicz, A.S. Tracey, in: H. Sigel, A. Sigel (Eds.), In Metal Ions in Biological Systems: Stimulation of Enzyme Activity by
Oxovanadium Complexes, vol. 31, Marcel Dekker, New York, 1995, pp. 249-285 (Chapter 8).

[9] (a) P. Zimmet, K.G.M.M. Alberti, J. Shaw, Nature 414 (2001) 782 787 ;

(b) D.E. Möller, Nature 414 (2001) 821-827.

[10] (a) H. Sakurai, Y. Kojima, Y. Yoshikawa, K. Kawabc, H. Yasui, Coord. Chem. Rev. 226 (2002) 187-198;

(b) T. Sasagawa, Y. Yoshikawa, K. Kawabc, H. Sakurai, Y. Kojima, J. Inorg. Biochem. 88 (2002) 108-112;

(c) K. Kanamori, K. Nishida, N. Miyata, K. Okamoto, Y. Miyoshi, A. Tamura, H.J. Sakurai, Inorg. Biochem. 6 (2001) 649-656;

(d) M. Melchior, S.J. Rettig, B.D. Liboiron, K.H. Thompson, V.G. Yuen, J.H. McNeill, C. Orgiv, Inorg. Chem. 40 (2001) 46864690.

[11] G.J. Colpas, B.J. Hamstra, J.W. Kampf, V.L. Pecoraro, J. Am. Chem. Soc. 118 (1996) 3469.

[12] A.D. Keramidas, A.B. Papaioannou, A. Vlahos, T.A. Kabanos, G. Bonas, A. Makriyannis, C.P. Rapropoulou, A. Terzis, Inorg. Chem. 118 (1996) 3469.

[13] K.K. Nanda, S. Mohanta, S. Ghosh, M. Mukherjee, M. Helliwell, K. Nag, Inorg. Chem. 34 (1995) 2861.

[14] C.R. Cornman, E.P. Zovinka, Y.D. Boyajian, K.M. Geiser-Bush, P.D. Boyle, P. Singh, Inorg. Chem. 34 (1995) 4213.

[15] C.J. Carrano, M. Mohan, S.M. Holmes, R. de la Rosa, A. Butler, J.M. Charnock, C.D. Garner, Inorg. Chem. 33 (1994) 646.

[16] D.C. Crans, P.K. Shin, J. Am. Chem. Soc. 116 (1994) 1305.

[17] E.M. Armstrong, R.L. Beddoes, L.J. Calviou, J.M. Charnock, D Collison, N. Ertok, J.H. Naismith, C.D. Garner, J. Am. Chem. Soc. 115 (1993) 807.

[18] M.J. Clague, N.L. Keder, A. Butler, Inorg. Chem. 32 (1993) 4754.

[19] V. Vergopoulos, W. Priebsch, M. Fritzsche, D. Rehder, Inorg. Chem. 32 (1844) 1844.

[20] C.R. Cornman, J. Kampf, M.S. Lah, V.L. Pecoraro, Inorg. Chem. 31 (1992) 2035.

[21] A.R. Bulls, C.G. Pippin, F.E. Hahn, K.N. Raymond, J. Am. Chem. Soc. 112 (1990) 2627.

[22] (a) M. Sutradhar, G. Mukherjee, M.G.B. Drew, S. Ghosh, Inorg. Chem. 45 (2006) 5150;

(b) Y. Miyazaki, S. Matsuoka, Y. Miura, H. Sakashita, K. Yoshimura, Polyhedron 24 (2005) 985;

(c) A. Sarkar, S. Pal, Polyhedron 25 (2006) 1689.

[23] (a) M.S. Shongwe, H.N.R. Al-Kharousi, H. Adams, M.J. Morris, E. Bill, Inorg. Chem. 45 (2006) 1103;

(b) M.R. Maurya, A. Kumar, M. Abid, A. Azam, Inorg. Chem. Acta 359 (2006) 2439

[24] A.K. Barik, S. Paul, R.J. Butcher, J.C. Bryan, S.K. Kar, Polyhedron 18 (1999) 571.

[25] (a) L. Papathanasis, M.A. Demertzis, P.N. Yadav, D. KovalaDemertzi, C. Prentjas, A. Castiñeiras, S. Skoulika, D.X. West, Inorg. Chim. Acta 357 (2004) 4113;

(b) D.X. West, S.B. Padhye, P.B. Sonawane, Struct. Bonding 76 (1991) 1 ;

(c) D.X. West, A.E. Liberta, S.B. Padhye, R.C. Chikate, P.B. Sonawane, A.S. Kumbhar, R.G. Yerande, Coord. Chem. Rev. 123 (1993) 49.

[26] D.D. Perrin, W.L.F. Armarego, D.R. Perrin, Purification of Laboratory Chemicals, second ed., Pergamon Press, Oxford, 1980.

[27] M. Akbar Ali, M.T.H. Tarafdar, J. Inorg. Nucl. Chem. 39 (1977) 1785.

[28] M.M. Mostafa, A El. Hammid, M. Shallaby, A.A. El-Asmy, Transit. Met. Chem. 6 (1981) 303.

[29] W.J. Geary, Coord. Chem. Rev. 7 (1971) 81.

[30] S.K. Chattopadhyay, D. Chattopadhyay, J. Banerjee, R. Kuroda, S. Ghosh, Polyhedron 16 (1997) 1925.

[31] S. Samanta, D. Ghosh, S. Mukhopadhyay, A. Endo, Timothy J.R. Weakley, M. Chaudhury, Inorg. Chem. 42 (2003) 1508.

[32] E. Kwiatkowski, G. Romanowski, W. Nowicki, M. Kwiatkowski, K. Suwinska, Polyhedron 22 (2003) 1009. 
[33] R. Dinda, P. Sengupta, S. Ghosh, T.C.W. Mak, Inorg. Chem. 47 (2002) 1684, and references cited therein.

[34] E.L. Muetterties, L.J. Guggenberger, J. Am. Chem. Soc. 96(1974) 1748.

[35] A.W. Addison, T.N. Rao, J. Reedijk, J. Rijn, G.C. van Verschoor, J. Chem. Soc., Dalton Trans. (1984) 1349.
[36] H. Schmidt, M. Bashirpoor, D. Rehder, J. Chem. Soc., Dalton Trans. (1996) 3865.

[37] G. Asgedom, A. Sreedhara, J. Kivikoski, E. Kolehmainen, C.P. Rao, J. Chem. Soc., Dalton Trans. (1996) 93.

[38] D. Cremer, J.A. Pople, J. Am. Chem. Soc. 97 (1995) 1354. 